\title{
科学技術と産業経済
}

\section{迫水久 常*}

私は, 今, 経済企画庁で, いわゆる所得倍増計画と取り組んでいる。終戦直後, 戦 前の $60 \%$ 程度に落ち込んでしまった日本の経済は, 国民の協力一致の努力によっ て, 7 カ年の後には戦前の規模に帰り, さらに大いに成長して, 今日では戦前の 2 倍になっている。この成長力の旺盛な日本経済が今後 10 年を期して, さらに 2 倍 になることを確保するために，この所得倍増の計画を策定しつつあるのである。す なわち, 目標年度たる昭和 45 年度において, 国民総所得 (国民総生産) を 26 兆円 以上になることを確実ならしめるための諸方策を策定するのである。

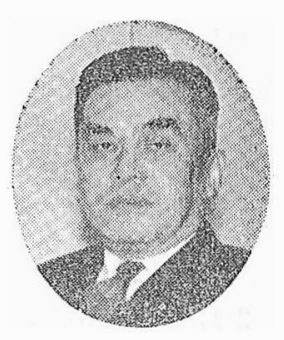

このように日本経済が成長するためには, 1 年平均 $7.2 \%$ 程度の成長率を保つことが必要であるが，日 本経済にとって, この程度の成長率を保つことは, さして困難なことではない。実際問題として, もし政 府が意欲的に施策を講ずるならば, 年平均 $10 \%$ の成長を期待することも決して無理ではないであろう。 池田総理は, 現にこの積極的な傾向を考光て抒られるのである。

経済成長の実体は，いうまでもなく生産の増加であるが，自由主義経済たる日本では，この生産増加は 民間企業の担当するところであって，政府が直接統制したり干渉したりすべきところではない。したがっ て計画の問題点は, この経済成長を円滑に進行せしめるためには, 政府としていかなる施策を講ずべきか という点にある。

講ずベき施策の内容はいろいろある。道路港湾なぞ，いわば経済の容器とでもいうべき公共施設を整備 する問題, 経済成長のために必要な土地を確保する問題, 水の問題, エネルギーの問題, 所要資金につい ての量および金利の問題など，幾多の問題があるが，いらばんの重要問題は「人」の問題である。

所得倍増を実現するためには, 工業は現在の 4 倍くらい, ことに機械工業は 8 倍ほどに拡大せられなけ ればならない。そうしてこの場合, 要求されるのは技術者であるが, 実情はあまりにも不足している。政 府としても，もちろん，高等学校拉よび大学を通じて理科系を増すために最善の努力をするのであるが， 果してそれで間に合らかといらことになると，すこぶる不安なきをえない。

そこで私は提案したい。それは現在, 丸善石油が実施して成功しているごとく, また不二越鋼材が戦前か ら実行して大きな成果を納めてるように, この際, 大企業が技術者養成のために高等学校あるいは大学を 開設してもららことである。その学校はその会社のための技術者に限定することなく, 広く一般の技術者 養成機関として経営されることが望ましい。そしてまた，これは現在も多くの会社が実行していると思う が, 往昔の軍の委託学生の制度のように, 優秀な, しかし経済力のない学生に対する給費制度を十分に拡 大してほしいと思ら。

科学技術のことは何年も前から声を大にして叫ばれており, 政府も一応の措置を講じて来たものの, 所 得倍増計画によって経済が急速に成長するとともに, 貿易為替の自由化によって日本企業の対外競争力の 培養が急速を要する事態に直面した今日，政府と民間とがほんとうに力を合わせてやらなければ間に合わ ないと思う。

私は, 毎日所得倍増計画と取り組みながら，全く気が気でないのである。

\footnotetext{
* 国務大臣・経済企画庁長官
} 